\section{Why Does Bank Performance Vary Across States?}

\section{Michelle Clark Neely David C. Wheelock}

\section{D} uring the 1980s, U.S. commercial banks failed in numbers not seen since the Great Depression. Unlike the failures of the Depression, however, failures in the 1980s were concentrated in just a handful of states; banks in most states fared well. Although the number of failures has since fallen back to fewer than 10 per year, regional differences in bank earnings persist. And although performance has varied more widely among states since 1980, bank earnings have never been uniform across states. Variation in performance among banks is not inherently bad, but it is nonetheless worthy of examination, especially if it reflects regulatory barriers that inhibit diversification and thus promote instability.

Much of the distress felt by banks in the Southwest and New England in the 1980s and early 1990s resulted from sharp economic declines in those regions. Restrictions on branching have historically limited the geographic scope of bank operations, and they surely represent an important reason why American banks are unusually vulnerable to local ized economic distress. The Riegle-N eal Interstate Banking and Branching Efficiency Act of 1994 substantially removed legal barriers to interstate branching beginning June 1 , 1997. One purpose of this article is to suggest how this legislation might alter the future structure of the U.S. banking industry by illustrating how branching restrictions have affected banking markets and performance in the past.

We argue that, although branching restrictions have contributed significantly to interstate differences in bank performance, they are not the whole story. First, pre-1997 branching restrictions did not prevent geographic diversification altogether, and the failure of many banks to exploit al ready existing diversification opportunities suggests that the new freedom to branch across state lines will not eliminate their vulnerability to regional economic declines. Second, non-branchingrelated bank regulations continue to differ at the state level, contributing to observed differences in bank earnings across states. Because policies in some states have attracted specialized banks such as credit card subsidiaries of bank holding companies, we investigate the impact of these policies on the variation in state-level bank earnings. We also examine whether loan loss provisions taken by money center banks and other large banks in the 1980s contributed to the increased dispersion of state-level bank earnings in those years. Although these factors had some effect, we conclude that the significant increase in the dispersion of state-level bank earnings since 1980 can be attributed largely to substantial differences in state economic conditions that emerged in the 1980s and early 1990s.

\section{BANKING PERFORMANCE AT THE STATE LEVEL}

We focus on the state as the relevant political division by which to measure regional differences in banking performance. In the United States, bank regulations are promulgated at both the federal and state levels. Branching restrictions, in particular, have traditionally been determined by states and, before 1997, interstate branching opportunities were severely limited. ${ }^{1}$ Interstate operation of bank holding companies provides only a partial
1 In 1992, New York enacted the first legislation permitting interstate branching. Similar legislation followed in Alaska, North Carolina, and Oregon, with each state requiring reciprocal treatment of its banks by any other state whose banks sought to open branches in the first state. Because the McFadden Act of 1927 prohibited interstate branching by national banks, the state legislation, in effect, applied only to state-chartered banks. Recently, however, the Comptroller of the Currency has granted de facto permission for some interstate branching by national banks, basing its stand on a legal interpretation that national banks may move their head office within a distance of 30 miles, including across state lines, while retaining all existing branches. 
2 Throughout this article, we compute return on average assets as net bank income during a calendar year, divided by the average of total bank assets at the end of the current and previous years. Return on average equity is computed similarly. Our data are for all insured U.S. commercial banks. For 1980-95, the source of these data is the Reports of Condition and Income (call reports). For 1948-79, our data source is FDIC (1993).

3 The annual average failure rate is defined as the average, across the 16 -year period, of the number of bank failures in a year divided by the number of banks operating at year end of the same year. The source for these data is the FDIC.

4 The average annual standard deviation of ROA for all U.S. banks (total U.S. bank eamings divided by total U.S. bank assets) between 1980 and 1995 is 0.0028 ; the average coefficient of variation (i.e., the standard deviation divided by the mean) is 0.3820 . The average annual standard deviation of the mean ROA across all states between 1980 and 1995 is 0.0050 , and the average annual coefficient of variation is 0.6296 .

5 Alaska and Hawail are included from 1959-95 only. substitute for interstate branch banking and, in any event, bank holding companies have been permitted to cross state lines only since 1982 (except for a few interstate operations pre-dating state prohibitions).

Between World War II and 1980, commercial bank earnings were generally stable and few banks failed. During the 1980s, however, bank earnings fluctuated widely from year to year and bank failures increased sharply. Between 1980 and 1995, failures and mergers caused the number of commercial banks in the United States to decline by more than one-third. During these 16 years, the after-tax earnings of commercial banks ranged from a low of $\$ 2.7$ billion (in 1987) to a record $\$ 48.3$ billion (in 1995), while return on average assets (ROA) ranged from 0.09 percent (in 1987) to 1.17 percent (in 1993). . Even if one ignores 1987, when earnings figures were distorted by extraordinarily large increases in the loan loss provisions of large regional and money center banks, the range of ROA between 1980 and 1995 was still larger than during the prior 36 years. The comparative instability in annual ROA since 1980 is illustrated in Figure 1.

The contrast between the stability of 1946-79 and the instability of 1980-95 is evident not only in bank earnings, but also in the number of bank failures, as Figure 2 illustrates. Before 1980, 10 or more failures had occurred in only three of the 34 years-1975, with 14 failures; 1976, with 17; and 1979, with 10. Between 1980 and 1994, however, at least 10 failures occurred every year. There were more than 100 failures in eight of those years and more than 200 failures in three years (1987, 1988, and 1989).

\section{Performance Variation Among U.S. Banks}

The performance of U.S. banks since 1980 has varied considerably across states. Commercial bank losses and failures were most common in the Southwest, especially Oklahoma and Texas, and in N ew England, after the collapse of the real estate markets in those regions. Banks in other regions have performed comparatively well. Four states-Delaware, Idaho, N evada, and South Carolina-had just one bank failure each between 1980 and 1995. Two states, however, had more than 100 failures over the same period: Oklahoma (117 failures) and Texas (525 failures). Both states had unusually large numbers of banks, however; adjusting for differences between states in the number of operating banks, we found that the rate of annual average bank failures ranged from 0.02 percent (in Wisconsin) to 4 percent (in Alaska and Connecticut) between 1980 and 1995. ${ }^{3}$

Commercial bank earnings also varied considerably between states from 1980 through 1995. State-level commercial bank ROA (measured as total bank earnings in a state, divided by the average of total bank assets in the state at the beginning and end of the year) ranged from a low of -4.10 percent in Alaska in 1987 to 4.33 percent in Nevada in 1994. In a typical year during 1980-95, the dispersion of bank earnings across states was roughly twice the dispersion of average U.S. bank earnings between years. ${ }^{4}$ Thus, while the U.S. banking industry as a whole was on a roller-coaster ride between 1980 and 1995, with considerable performance variation across time, the differences in bank performance among states were even more striking.

\section{Changing Geographic Dispersion of Earnings}

A plot of the coefficient of variation of bank earnings at the state level in different years illustrates how the extent of geographic dispersion in earnings has changed over time. Figure 3 plots the coefficient of variation of bank ROA and ROE (return on average equity) across states for 1947-95. ${ }^{5}$ As is evident, the differences in bank earnings among states were considerably larger during the 1980s and early 1990s than during any other postwar period. The cross-state variation was especially pronounced between 1986 and 1991, which encompassed the periods of acute bank distress in both energy-producing states and $\mathrm{New}$ England, a substantial increase in loan loss provisions associated with loans 
to lesser-developed countries (LDCs), and a recession. Still, by the standards of 1947-79, bank earnings also varied a great deal across states in 1980-85 and from 1991 through the period of our research.

\section{BANK PERFORMANCE DIFFERENCES-THE ROLE OF LOCAL ECONOMIES}

The extent of geographic variation in state per capita incomes provides a standard of comparison for evaluating interstate differences in commercial bank earnings. Figure 4 plots the coefficient of variation of state per capita incomes during 1946-95. With little interruption, state per capita incomes grew closer together from 1946 to 1972 . Per capita income dispersion increased sharply during the severe recession of 1974, but then declined until 1980. From 1980 to 1988, state per capita incomes became more dispersed, suggesting a link to the increased dispersion of bank earnings among states. Since 1989, however, the trend toward less dispersion in per capita income has resumed and, accordingly, the coefficient of variation has declined.

Coughlin and Mandelbaum (1988) examine several alternative explanations for the increased geographic variation in per capita incomes during the 1980s and conclude that the principal cause was the decline in energy prices and the resulting drop in energy-state incomes over those years. That bank performance in energyproducing states also suffered in these years suggests that the divergence of state incomes was a likely source of the divergence in bank earnings and failure rates. Sherwood-Call (1996), however, argues that rapid growth associated with hightech manufacturing in northeastern states explains most of the divergence of per capita incomes during the $1980 \mathrm{~s}$. The relatively poor performance of $\mathrm{N}$ ew England banks in the late 1980s and early 1990s suggests, therefore, that differences in per capita income growth alone might not explain the divergence of state-level bank earnings.

Amos (1983) finds that the dispersion

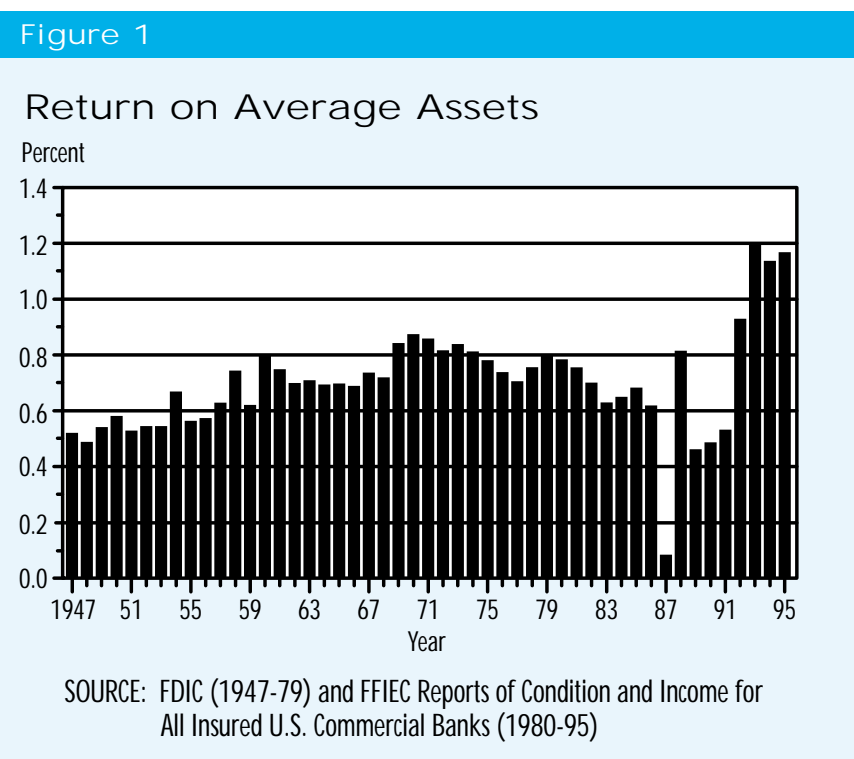

Figure 2

\section{U. S. Bank Failures}

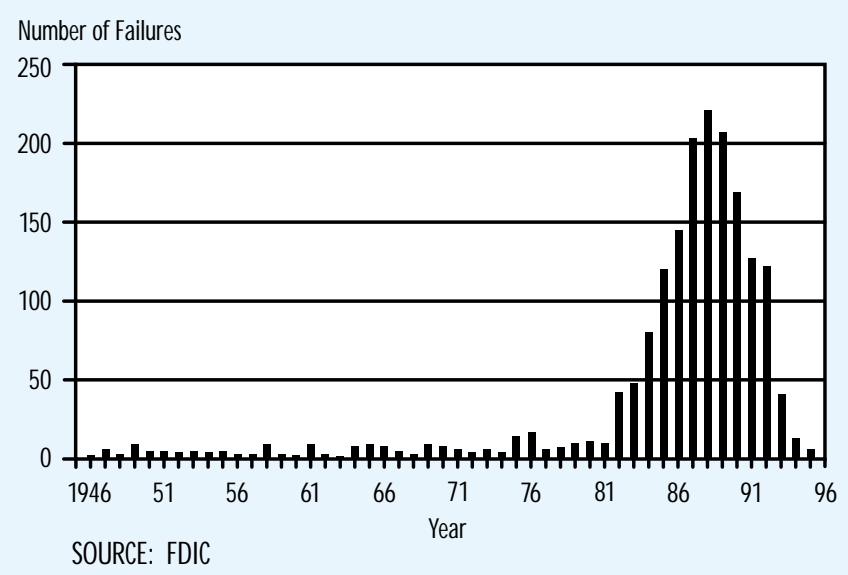

of state per capita incomes generally widens when national income declines. Although small in comparison with statelevel differences in bank earnings during the 1980s, interstate differences in bank earnings have also widened during some recessions. A plot of the coefficient of variation of state-level ROA and ROE from 1947 to 1980 (Figure 5) illustrates increased variation in bank earnings during recessions in 1954, 1958, 1970, and 1974. Since 1946, bank earnings dispersion has declined during recessions only in 1948, 1960, and 1990-91, all of which 


\section{Figure 3}

\section{Coefficient of Variation}

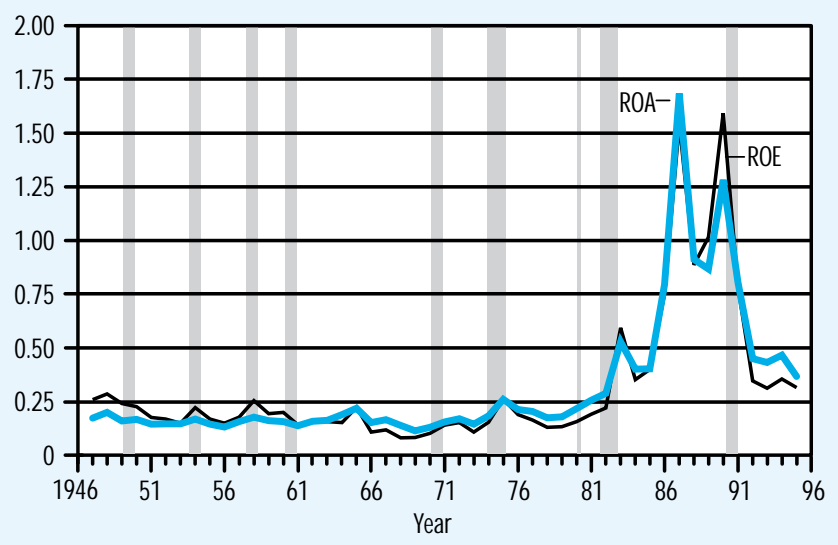

Figure 4

\section{Coefficient of Variation of Per Capita Income}

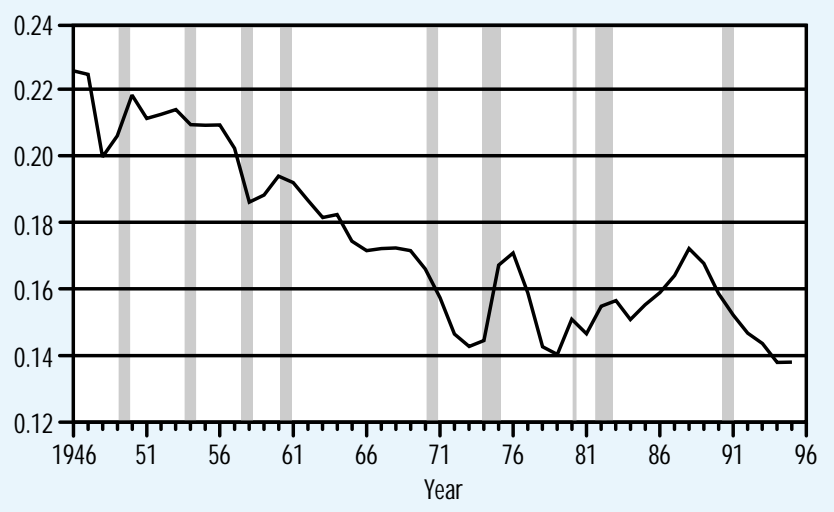

were periods of relatively minor economic downturns. Given legal restrictions on branch banking, the tendency of state income differentials to widen during recessions may account for the concurrent increased dispersion of bank earnings among states in some of these episodes.

\section{Effects of Government Bank Charter Policy}

Government policy toward granting

6 For a discussion of chartering policy, see Spong (1994), especially pp. 124-28. bank charters may explain why the dispersion of state-level bank earnings did not increase during all recessions. Before
1980, the Comptroller of the Currency's chartering policy for national banks was designed to ensure that bank failures rarely occurred. Applications for bank charters were commonly denied to protect the earnings of existing banks. This policy helped banks in economically depressed areas to more easily achieve profit rates comparable to those of banks located elsewhere without having to assume unusually high credit risk. Consequently, the policy may have diminished the impact of local economic conditions on the geographic dispersion of bank earnings. Indeed, we find some evidence that changes in state-level income had a smaller effect on state-level bank earnings before 1980 than since- a finding that may reflect, at least in part, the reorientation of chartering policy away from one designed to limit competition. ${ }^{6}$

The easing of chartering policy was followed by an easing of branch banking restrictions in many states and, finally, by federal legislation, which became effective in 1997. Perhaps the most prominent argument in favor of interstate branching is that it provides banks with increased opportunities to diversify their loan portfolios and deposit bases. Greater geographic diversification would make it easier for banks to offset losses incurred in one region with profits from another, and it would, presumably, make the industry less vulnerable to localized economic distress like that of the 1980s and early 1990s. In the early 1980s, banks in farm states suffered as the agricultural economy declined. More dramatic was the decimation of large portions of the banking industry in Texas and other energy-producing states in the mid-1980s, and in New England after the region's real estate collapse in 1990-91. Arguably, there would have been fewer bank failures had banks in these regions been better diversified, with asset holdings from many different regions.

\section{The Rise of Interstate}

\section{Bank Holding Companies}

Interstate operation of bank holding companies provides at least a partial substitute for interstate branch banking. 
The parent organization of a holding company operating in multiple states is itself diversified geographically. Moreover, a bank subsidiary may be able to withstand an economic downturn in its local market better if it benefits from the financial strength of a parent operating over a wide area. ${ }^{7}$ The share of industry assets controlled by multiple bank holding companies has increased rapidly since 1980 , when just 16 multi-state holding companies held 4 percent of industry assets. Since the depressed earnings years of 1986-91, the growth of bank holding companies has been especially rapid and, by the middle of 1995, 250 multi-state holding companies held approximately 75 percent of industry assets (Ludwig, 1996).

If the multi-bank holding company organizational form is winning a "survival of the fittest" struggle with the independent bank and one-bank holding company form, it may be a reflection of better diversification. And, thus, if multi-bank holding companies continue to amass an increasing share of the banking industry, differences in bank-level performance among states may become smaller, or at least less important. ${ }^{8}$ Because there were few holding companies with significant interstate operations before the late 1980s, however, commercial bank performance at the state level was probably strongly influenced by local economic conditions throughout the period of our study.

\section{State Economic Activity and Commercial Bank Earnings}

We perform a simple test of the effect of state-level economic activity on commercial bank earnings by regressing state-level bank earnings on annual percentage changes in state per capita incomes. ${ }^{9}$ Specifically, we estimate a pooled timeseries, cross-sectional model of state-level ROA $\left(R_{0} A_{i t}\right)$ and ROE $\left(R_{i t}\right)$ on the current and previous year's percentage changes in state per capita income $\left(\% \Delta Y_{i}\right)$. Our time series includes annual observations during 1949-95 on 48 states (Alaska and Hawaii are excluded). We also include dummy variables for each state

\section{Figure 5}

\section{Coefficient of Variation}

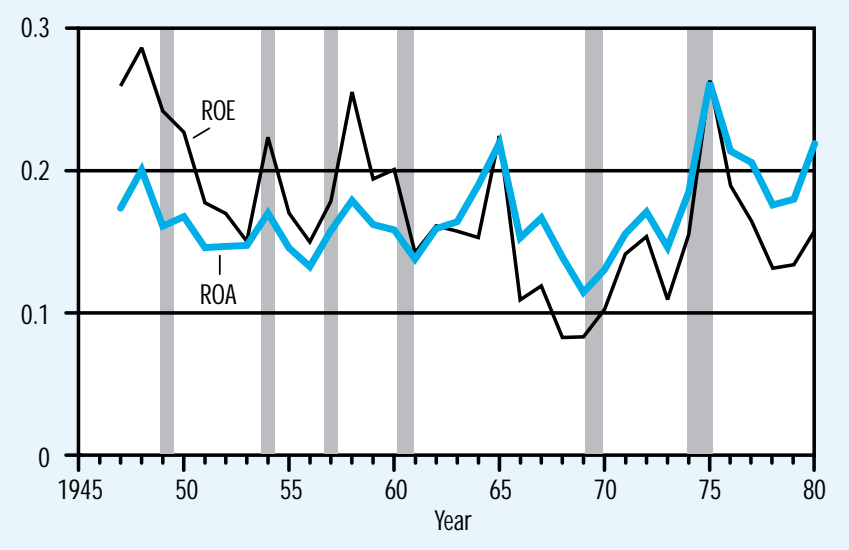

and year of the estimation period, to control for state-level and year effects on bank earnings apart from current economic activity.

Our regression results, along with descriptive statistics, are reported in Table 1. Separate models were estimated for the entire period, 1949-95, and for 1981-95 alone. The findings indicate that statelevel bank earnings are strongly affected, in a statistical sense, by state-level per capita income growth. The larger the percentage increase in a state's income growth, in either the current or previous year, the higher the state's bank ROA (models 1 and 3 ) and ROE (models 2 and 4). If the investment and deposit bases of banks were extensively diversified across states, we would not expect to find this systematic relationship between a bank's earnings and the per capita income of the state in which it is headquartered.

Although our regressions indicate that commercial bank earnings are influenced by per capita income growth at the state level, they also reveal that state income growth explains a relatively small amount of the variation in bank earnings. The coefficients on current and lagged per capita income growth, though statistically significant, are economically small. Based on the coefficient for current income growth in model 1, a one-half standard deviation increase in per capita income
7 See Rose (1995) for evidence on the extent to which interstate banking can make bank earnings more stable, and Gilbert (1991) for evidence about the extent to which bank holding companies inject capital into their weak bank subsidiaries.

${ }^{8}$ One reason why differences in state-level bank earnings may become less important with the spread of interstate banking is that federal legislation requires that the capital of all bank subsidiaries of a holding company be available to cover any losses to the $F D I C$ resulting from the failure of any bank affiliate of the holding company.

9 Samolyk (1994a) examines several state-level measures of commercial bank performance during 1984-92 and finds that performance reflected both local economic conditions and banking market structure, as indicated by bank size and holding company affiliation. 


\section{Table 1}

\section{The Effect of State Income on Commercial Bank Earnings}

1949-95 (Models 1 and 2)

1981-95 (Models 3 and 4)

\begin{tabular}{lllll} 
Model & $(1)$ & $(2)$ & $(3)$ & $(4)$ \\
\hline Dependent Variable: & $R O A_{i t}$ & $R O E_{i t}$ & $R O A_{i t}$ & $R O E_{i t}$ \\
Intercept & 1.31 & 14.63 & 0.96 & 8.58 \\
& $(22.54)^{*}$ & $(18.06)^{*}$ & $(8.24)^{*}$ & $(4.98)^{*}$ \\
\hline$\% \Delta Y_{i}$ & 0.014 & 0.219 & 0.067 & 1.026 \\
& $(6.72)^{*}$ & $(7.44)^{*}$ & $(8.97)^{*}$ & $(9.20)^{*}$ \\
\hline$\% \Delta Y_{\text {it-1 }}$ & 0.014 & 0.225 & 0.057 & 0.849 \\
& $(6.94)^{*}$ & $(8.07)^{*}$ & $(8.33)^{*}$ & $(8.30)^{*}$ \\
\hline Adjusted $R^{2}$ & 0.422 & 0.331 & 0.565 & 0.417 \\
F-statistic & $18.32^{*}$ & $12.74 *$ & $15.82^{*}$ & $9.15^{*}$
\end{tabular}

NOTES: Each regression coefficient has been multiplied by 100 ; t-statistics in paratheses; * indicates statistically significant at the .01 level; all models were estimated with state and year dummy variables (not shown).

Descriptive Statistics, 1949-95 (2,256 observations)

\begin{tabular}{lll}
\hline Variable & Mean & Standard Deviation \\
\hline$R O A_{i t}$ & 0.00805 & 0.00363 \\
$R O E_{i t}$ & 0.11099 & 0.04713 \\
$\% \Delta Y_{i}$ & 6.20465 & 4.27626 \\
$\% \Delta Y_{\text {it-1 }}-\% \Delta Y_{\text {ust- } 1}$ & 6.30498 & 4.40977
\end{tabular}

Descriptive Statistics, 1981-95 (720 observations)

\begin{tabular}{lll}
\hline Variable & Mean & Standard Deviation \\
\hline$R O A_{i t}$ & 0.00902 & 0.0571 \\
$R O E_{i t}$ & 0.11994 & 0.07326 \\
$\% \Delta Y_{i}$ & 5.80144 & 2.71436 \\
$\% \Delta Y_{\text {it-1 }}-\% \Delta Y_{\text {ust-1 }}$ & 6.12018 & 2.96912
\end{tabular}

growth (2.14 percentage points) translates into an increase in ROA of only 0.08 of one standard deviation. In other words, for a state with an average bank ROA of 0.81 percent (the mean state-level ROA over the entire period), a 2.14 percentage point increase in the growth rate of state per capita income (an increase of some one-third relative to the mean) would increase ROA to just 0.84 percent. Similarly, if one uses the coefficient for income growth in model 2, a 2.14 percentage point increase in the growth rate of per capita income would generate a
0.10 standard deviation increase in ROE (thus, at the mean, raising ROE from 11.10 percent to 11.57 percent).

The impact of current income on bank earnings appears to have been greater during 1981-95 than during 1949-80. Based on the coefficients from models 3 and 4, a one-half standard deviation increase in the percentage growth rate of the current year's per capita income (1.35 percentage points) translates into a 0.16 standard deviation increase in ROA and a 0.19 standard deviation increase in ROE. In other words, for a state with mean ROA, a 1.35 percentage point increase in the growth rate of the current year's per capita income would raise ROA from 0.90 percent to 0.99 percent. A similar increase in the growth rate of per capita income would raise the ROE of a state at the mean ROE from 11.99 percent to 13.38 percent. The increased importance of state-level income on state-level bank earnings since 1980 might reflect the decision of regulators to abandon their previous policy of considering the potential impact of new banks on the earnings of existing banks in a market. Whereas before 1980 chartering policy helped banks in economically weak areas to earn rates of return that were average for the industry without assuming extraordinary risk, the 1980 change in chartering policy may have more closely entwined banks' earnings with the economic fortunes of their local markets.

Even during the 1980s, however, per capita income does not explain fully statelevel bank earnings. State-level per capita income may not accurately capture the economic shocks affecting commercial bank earnings. In N ew England, for example, the proximate cause of the decline in commercial bank earnings was a decline in real estate values. A sharp downturn in a sector, such as real estate, could dramatically affect bank earnings without having a large impact on per capita income. Moreover, $\mathrm{N}$ ew England banks tended to have more of their assets in real estate loans (31.4 percent in 1984) than did banks in other regions (22.0 percent for all U.S. banks, according to Peek 
and Rosengren, 1994) - suggesting that, ex ante, New England banks were exceptionally vulnerable to a collapse of real estate values.

\section{Effects of Varying Regulations and Market Structures}

Differences in commercial bank earnings across states might also be affected by differences in regulations or market structure that are independent of current per capita incomes. States that have long permitted statewide branch banking, for example, have different banking market structures than states with a history of branching restrictions. California, for example, which has permitted statewide branching since 1909, has many fewer banks per capita than Texas, which has permitted extensive branching only since 1987. Such differences might contribute to long-term differences in commercial bank earnings between the two states. Regulation and market structure might also interact with general economic conditions. For example, an adverse shock to agriculture might affect banks less in a state where banks are well diversified between urban and rural areas. ${ }^{10}$

Some states have enacted legislation that permits (or encourages) entry by limited purpose banks, such as credit card banks. In the 1980s, credit card operations were especially profitable and, as we demonstrate below, the presence of such banks has had a marked influence on statelevel bank earnings rates. Finally, average bank earnings in some states are dominated by large money center banks with extensive international operations. Many would question the comparability of such banks with the much smaller banks that predominate in most states. Certainly, shocks specific to one type of bank - a widespread default on loans by lesser-developed countries, for example-could affect state-level differences in bank earnings.

By including state dummy variables in our regressions, we have taken one step toward capturing idiosyncratic influences on state-level bank earnings other than current income growth. As a whole, the dummy variables contribute a statistically significant amount of explanatory power

(with F-tests all significant at the 0.01 level).

In Table 2, we report, from smallest to largest, the estimated coefficients for the state dummy variables from models 1 and 2 of Table 1 (Wyoming is the omitted state). The rankings of these coefficients between the two models are similar. Among the states with the largest negative coefficients are some in the Southwest (Arizona, California, and Texas), the South (Louisiana), the N ortheast (Connecticut, Massachusetts, and Vermont), and states with large money center banks, specifically $\mathrm{N}$ ew York and Illinois. Average bank earnings in these states were all below what state per capita income growth alone would predict. For example, against a mean ROA of 0.81 percent $(0.0081)$, a dummy variable coefficient of -0.34 percent (- 0.0034) implies that average bank ROA in Arizona between 1949 and 1995 was approximately one-half that predicted by current state income growth alone. Similarly, against a mean ROE of 11.1 percent (0.111), a dummy variable coefficient of - 4.0 percent $(-0.040)$ implies that average bank ROE in Connecticut between 1949 and 1995 was 36 percent less than what state income growth alone would predict.

At the other extreme, three statesSouth Dakota, N evada and Delaware - had unusually large positive dummy variable coefficients in the ROA specification (model 1). South Dakota and Nevada had the largest coefficients in the model of ROE (model 2). These states had considerably higher average bank earnings than state per capita income growth alone would predict.

\section{Performance Over Time}

An important caveat about the regression results presented here is that we have no reason to expect that the relationships are stable over time. Indeed, the estimates reported in Table 1 suggest that the relationships between current income growth and bank earnings were stronger during 1981-95 than during 1949-80, perhaps because of a change in bank chartering

\footnotetext{
${ }^{10}$ Samolyk (1994b) finds that banking conditions are more closely related to current economic conditions in states where the banking system is in a weakened condition, suggesting an interaction of economic conditions with market structure.
} 


\section{Table 2}

\section{State Dummy Variable Coefficients 1949.95}

\begin{tabular}{|c|c|c|c|c|c|c|c|}
\hline \multicolumn{4}{|c|}{ Model 1} & \multicolumn{4}{|c|}{ Model 2} \\
\hline State & Coefficient & State & Coefficient & State & Coefficient & State & Coefficient \\
\hline$A Z$ & -0.0034 & $N C$ & -0.0010 & CT & -0.0400 & IA & -0.0094 \\
\hline CT & -0.0032 & VA & -0.0009 & TX & -0.0291 & NM & -0.0085 \\
\hline NY & -0.0028 & ME & -0.0009 & MA & -0.0274 & Wl & -0.0080 \\
\hline$C A$ & -0.0027 & MO & -0.0008 & NY & -0.0255 & WA & -0.0079 \\
\hline TX & -0.0026 & UT & -0.0008 & VT & -0.0233 & VA & -0.0072 \\
\hline MA & -0.0024 & $A R$ & -0.0006 & $A Z$ & -0.0226 & MO & -0.0066 \\
\hline IL & -0.0020 & MT & -0.0006 & LA & -0.0200 & KY & -0.0050 \\
\hline NJ & -0.0019 & ID & -0.0006 & OK & -0.0184 & MS & -0.0036 \\
\hline VT & -0.0019 & NH & -0.0005 & $\mathrm{NH}$ & -0.0182 & GA & -0.0024 \\
\hline LA & -0.0019 & MS & -0.0005 & IL & -0.0166 & $O R$ & -0.0013 \\
\hline RI & -0.0017 & KS & -0.0003 & $\mathrm{TN}$ & -0.0157 & $\mathrm{AL}$ & -0.0009 \\
\hline NM & -0.0016 & IA & -0.0003 & PA & -0.0156 & $\mathrm{Ml}$ & -0.0008 \\
\hline $\mathrm{FL}$ & -0.0016 & $\mathrm{OH}$ & -0.0002 & $\mathrm{NJ}$ & -0.0144 & SC & -0.0002 \\
\hline TN & -0.0016 & KY & -0.0001 & ME & -0.0139 & $\mathrm{OH}$ & -0.0001 \\
\hline $\mathrm{CO}$ & -0.0015 & GA & -0.0001 & $\mathrm{Rl}$ & -0.0136 & $\mathrm{NE}$ & 0.0007 \\
\hline WA & -0.0014 & SC & -0.0001 & MD & -0.0136 & ND & 0.0024 \\
\hline MI & -0.0014 & ND & 0.0000 & $\mathrm{CO}$ & -0.0127 & NC & 0.0034 \\
\hline MN & -0.0014 & $\mathrm{AL}$ & 0.0003 & WV & -0.0127 & MT & 0.0044 \\
\hline MD & -0.0013 & NE & 0.0004 & $A R$ & -0.0125 & UT & 0.0055 \\
\hline IN & -0.0013 & WV & 0.0005 & $\mathrm{FL}$ & -0.0119 & $D E$ & 0.0096 \\
\hline OK & -0.0013 & $D E$ & 0.0026 & IN & -0.0106 & ID & 0.0130 \\
\hline PA & -0.0012 & NV & 0.0029 & $C A$ & -0.0102 & SD & 0.0401 \\
\hline OR & -0.0011 & SD & 0.0036 & KS & -0.0098 & NV & 0.0403 \\
\hline WI & -0.0011 & $\begin{array}{l}\text { Mean } \\
\text { on Av } \\
\text { Assets }\end{array}$ & 0.0081 & MN & -0.0097 & $\begin{array}{l}\text { Mean } \\
\text { on Av } \\
\text { Equity }\end{array}$ & $\Rightarrow 0.1110$ \\
\hline
\end{tabular}

NOTE: For Model 1, the coefficients for AZ through MI are statistically significant at the 0.01 level, as are those for DE, NV and SD. For Model 2, the coefficients for CT through LA are significant at the 0.01 level, as are those for SD and NV.

policy. In addition, although the rankings of state dummy variable coefficients for 1981-95 are similar to the rankings for the entire period from 1949 to 1995, they are not identical, as a comparison between Tables 2 and 3 reveals. For example, in the model of ROA estimated over 1981-95, the coefficients for Oklahoma and Texas are large and statistically significant. For the period 1949-95 as a whole, however, these state coefficients are considerably smaller and, in the case of Oklahoma, not significantly different from zero. For the period 1949-80 alone (not shown), neither state's coefficient is significant. A similar pattern exists for Delaware, N evada and South Dakota, all of which have large and statistically significant coefficients for 1981-95, but insignificant coefficients for 1949-80.

On the other hand, Arizona, California, and N ew York have among the largest negative coefficients for the model of ROA over 1949-95 as a whole, as well as for both subperiods, 1949-80 and 1981-95. For states with economically large (in absolute value) coefficients in the regressions throughout 1949-95, the idiosyn- 


\section{Table 3}

\section{State Dummy Variable Coefficients \\ 1981.95}

\begin{tabular}{llll|llll} 
& \multicolumn{3}{c}{ Model 3} & \multicolumn{5}{c}{ Model 4} \\
State & Coefficient & State & Coefficient & State & Coefficient & State & Coefficient \\
\hline CT & -0.0083 & VA & -0.0022 & CT & -0.1001 & WA & -0.0171 \\
NY & -0.0067 & NH & -0.0021 & TX & -0.0722 & PA & -0.0158 \\
AZ & -0.0066 & NC & -0.0020 & AZ & -0.0710 & MS & -0.0156 \\
MA & -0.0064 & MO & -0.0020 & NY & -0.0566 & UT & -0.0144 \\
TX & -0.0061 & ID & -0.0020 & MA & -0.0536 & MO & -0.0137 \\
NJ & -0.0045 & SC & -0.0018 & LA & -0.0445 & MT & -0.0126 \\
IL & -0.0043 & KS & -0.0018 & OK & -0.0429 & KY & -0.0109 \\
CA & -0.0041 & MI & -0.0017 & IL & -0.0376 & WV & -0.0105 \\
LA & -0.0038 & MS & -0.0015 & NJ & -0.0355 & RI & -0.0099 \\
OK & -0.0038 & MT & -0.0014 & ND & -0.0331 & NE & -0.0096 \\
VT & -0.0037 & AR & -0.0013 & MD & -0.0326 & SC & -0.0095 \\
MD & -0.0036 & IA & -0.0011 & VT & -0.0324 & VA & -0.0049 \\
CO & -0.0034 & KY & -0.0010 & CO & -0.0316 & AL & -0.0033 \\
RI & -0.0032 & GA & -0.0006 & TN & -0.0295 & ID & -0.0031 \\
TN & -0.0031 & NE & -0.0005 & CA & -0.0245 & GA & -0.0018 \\
PA & -0.0031 & OR & -0.0004 & KS & -0.0229 & WI & 0.0020 \\
FL & -0.0029 & WI & -0.0004 & IN & -0.0199 & MI & 0.0043 \\
ME & -0.0028 & AL & -0.0003 & AR & -0.0198 & OR & 0.0092 \\
UT & -0.0027 & WV & 0.0001 & ME & -0.0197 & NC & 0.0107 \\
MN & -0.0026 & OH & 0.0001 & NH & -0.0181 & OH & 0.0186 \\
ND & -0.0024 & DE & 0.0058 & NM & -0.0181 & DE & 0.0386 \\
NM & -0.0024 & NV & 0.0080 & IA & -0.0179 & NV & 0.0837 \\
IN & -0.0022 & SD & 0.0094 & MN & -0.0177 & SD & 0.0925 \\
WA & -0.0022 & Mean Return & & FL & -0.0173 & Mean Return \\
& & On Average & & & & on Average & \\
& & Assets (ROA) & 0.0090 & & & Equity (ROE) & 0.1199
\end{tabular}

NOTE: For Model 3 , the coefficients for CT through MD are statistically significant at the 0.01 level, as are those for DE, NV and SD. For Model 4, the coefficients for CT through MA are significant at the 0.01 level, as are those for NV and SD.

cratic characteristics that give them unusual bank earnings are of a long-term nature. Such characteristics might be dominance by money center banks or other large institutions or a long history of branch banking. A state with a large (in absolute value) coefficient in the regressions for 1949-95, but not for 1949-80, such as Texas or South Dakota, probably experienced a more recent development affecting bank earnings in the state. Texas banks, for example, suffered the brunt of falling energy prices and a collapse of state real estate values during the 1980s. Bank earnings in South Dakota, on the other hand, were buoyed by Citibank, S.D., and several other credit card banks, which had high rates of return in the 1980s. In the following section, we attempt to account for regulatory and market structure influences on commercial bank earnings differences across states.

\section{OTHER EXPLANATIONS FOR BANK PERFORMANCE DIFFEREN CES}

The regression results clearly indicate that state-specific factors, apart from state economic performance, account for a por- 


\section{Table 4}

\section{Return on Average Assets for Credit Card Bank States Versus All States}

\begin{tabular}{cccccc} 
Year & All U.S. Banks & $\begin{array}{c}\text { Me States } \\
\text { 50 }\end{array}$ & Delaw are & Nevada & South Dakota \\
\hline 1984 & $0.66 \%$ & $0.90 \%$ & $1.44 \%$ & $1.24 \%$ & $2.40 \%$ \\
\hline 1985 & 0.68 & 0.78 & 1.14 & 1.22 & 1.29 \\
\hline 1986 & 0.61 & 0.67 & 1.16 & 1.27 & 1.43 \\
\hline 1987 & 0.09 & 0.51 & 1.15 & 1.43 & 2.04 \\
\hline 1988 & 0.81 & 0.78 & 1.33 & 1.85 & 1.87 \\
\hline 1989 & 0.48 & 0.79 & 1.45 & 1.98 & 2.24 \\
\hline 1990 & 0.49 & 0.60 & 1.99 & 1.22 & 2.17 \\
\hline 1991 & 0.54 & 0.72 & 1.89 & 1.40 & 2.49 \\
\hline 1992 & 0.93 & 1.10 & 2.35 & 2.64 & 2.87 \\
\hline 1993 & 1.20 & 1.36 & 2.98 & 3.49 & 3.53 \\
\hline 1994 & 1.16 & 1.36 & 3.03 & 4.33 & 3.45 \\
\hline 1995 & 1.17 & 1.35 & 2.34 & 3.21 & 3.26
\end{tabular}

SOURCE: FFIEC Reports of Condition and Income

${ }^{11}$ As of March 1985, Delaware, Maryland, Nebraska, Nevada, South Dakota, and Virginia had limited purpose banking laws on their books, and a number of other states de facto permitted these types of institutions through interstate banking laws (see Whitehead 1985). For overviews and discussions of the rationale for limited purpose banking laws in Delaware, see Prickett, Swayze, and Spivack (1981) and Ripsom, Swayze, and Sheehan (1983).

12 The large gap between profit rates earned by credit card banks and full-service commercial banks has been analyzed extensively over the past five years. Researchers have observed that credit card interest rates appear invariant to banks' cost of funds, which accounts for high net interest margins. The higher risk and loss rates associated with credit cards and consumer reluctance to shop rates or switch cards appear to explain much of this profit. See Ausubel (1991), Sinkey and Nash (1993), and GAO (1994). tion of the variation in state ROA in any given year. By identifying and isolating these state-specific effects, we can better judge just how important they are in explaining this variation. Differences in average ROA and ROE for states in the 1980s were influenced by at least two special factors: extraordinarily large provisions taken by large regional and money center banks to cover anticipated losses from loans to LDCs, and the proliferation of generally high-profit credit card banks, other limited purpose banks, and the socalled nonbank banks in states permitting these institutions. These effects influenced average ROA figures dramatically for some states and account for a portion of the variation in average ROA across states in the 1980s.

\section{LDC Loan Loss Provisions}

In both 1987 and 1989, large regional and money center banks in the United States set aside millions, and in some cases billions, of dollars from current earnings to bolster loan loss reserves in anticipation of charge-offs of LDC debt, mostly in Latin American countries. Citicorp alone took a $\$ 3$ billion loan loss provision- equivalent to one-quarter of its outstanding LDC debt-in the second quarter of 1987 to cover expected losses (Todd, 1988, p. 32). For seven of nine U.S. money center banks, including Citicorp, these provisions exceeded the bank's pretax net interest income less net noninterest expense, resulting in negative pretax earnings in 1987.

The nine money center banks with significant foreign loan exposu re dramatically influenced average ROA in their states in 1987 and 1989. Without its six money center banks, N ew York would have posted state-level ROA of -0.05 percent in 1987, instead of its actual -0.66 percent. Similarly, ROA in Illinois rises from -0.23 percent to 0.51 percent when money center banks Continental Illinois and First Chicago are excluded. ROA rises from - 0.20 percent to 0.07 percent when Bank of America is dropped from Cal ifornia's average. For 1989, dropping the six $\mathrm{New}$ York-based money center banks increases ROA from - 0.48 percent to 0.11 percent.

Although the nine money center banks had a substantial impact on the ROA figures for their states, excluding them lowers the overall coefficient of variation of earnings dispersion across all states for 1987 by just 9 percent, from 1.69 to 1.54 . The coefficient of variation is reduced further in 1987 when additional banks with significant foreign loan exposure are dropped from the state calculations. Grammatikos and Saunders (1990) identify 35 regional and money center banks that announced significant additions to their loan loss reserves after Brazil's February 1987 announcement that it was suspending interest payments on its foreign debt. A part from New York, California, and Illinois, other states that show significant increases in average ROA when these 35 banks are dropped include Minnesota (ROA rises from 0.09 percent to 0.39 percent) and Pennsylvania (ROA rises from 0.22 percent to 0.55 percent).

Average ROA does not increase in every state where banks with significant foreign loan exposure are dropped, however, because a number of these banks were still more profitable than their peers. When all 35 banks (including the nine money center banks previously deleted) 
are excluded from the state ROA calculations, the coefficient of variation for 1987 falls further to 1.48 . But for the entire 1980-95 period, dropping the 35 banks from the calculation of 1987 ROA reduces the average annual coefficient of variation just one point, to 0.62 . It is apparent, therefore, that while the extraordinary loan loss provisions taken by large regional and money center banks in 1987 seriously reduced reported average earnings for U.S. banks in that year, these provisions had a relatively modest impact on the cross-state dispersion of average ROA in 1987 and for the period overall.

\section{Limited Purpose and Nonbank Banks}

Average state profitability ratios were also affected in the 1980s and 1990s by the existence of credit card banks and other limited purpose banks and nonbank banks. Unlike full-service commercial banks, limited purpose and nonbank banks specialize in a particular banking product-such as credit cards- and do not offer a full range of commercial banking services. These institutions sprang up in the early 1980 s as states sought to attract new capital and employment, and some large banking organizations sought to expand across state lines by exploiting loopholes in federal banking laws.

Delaware, South Dakota, and other states openly courted out-of-state banks in the early 1980s, passing legislation that allowed these banks to set up operations that specialized in credit cards, trust services, and other products. ${ }^{11}$ These banks, especially ones that focus on credit cards, tend to have much higher profit rates than their full-service counterparts. ${ }^{12}$ Thus, states with high concentrations of limited purpose banks tend to enjoy higher average bank profit rates than other states. In 1988, for example, when ROA for all U.S. banks was 0.81 percent, statelevel ROA was 1.33 percent for Delaware banks, 1.85 percent for N evada banks, and 1.87 percent for South Dakota banks. The spread between these states' ROA and that of all states was even wider in the late 1980s and early 1990s (see Table 4). N onbank banks have also affected average ROA in some states. The term "nonbank bank" was coined to describe companies that either accept demand deposits or make commercial loans, but do not do both. Since the Bank Holding Company Act of 1956 (amended 1970) defines banks as institutions that both accept demand deposits and make commercial loans, nonbank banks are technically not banks and thus are not bound by the law's interstate banking restrictions or its prohibition against commercial firms' ownership of banks. Bank holding companies circumvented the Act by chartering industrial banks and industrial thrift companies. These institutions made commercial and consumer loans but funded their activities with time deposits, rather than demand deposits, and were able to cross state lines because they were not technically banks. A number of bank holding companies, including Continental Illinois and Morgan Guaranty, launched banks to specialize in trust services in several states, including Florida, circumventing the "bank" label by not offering commercial loans. The number of nonbank banks jumped in the early 1980s when large numbers of nonfinancial companies (e.g., Sears, J.C. Penney) and diversified financial services companies (e.g., Household International, Beneficial Corp.) acquired banks that subsequently sold off their commercial loan portfolios. Both nonfinancial and financial firms set up credit card banks in a number of states that met the definition of nonbank banks. ${ }^{13}$

Because limited purpose and nonbank banks tend to post returns that differ markedly from full-service banks, their presence in the data tends to affect statelevel ROA, especially for small states with few banking organizations, like Delaware and South Dakota. Deleting these banks reduces ROA for all U.S. banks during the 1980s and 1990s by up to seven basis points; reductions in an individual state's ROA are significantly larger (see Table 5). ${ }^{14}$ For example, ROA for all U.S. banks in 1992 declines from 0.93 percent to 0.87
${ }^{13}$ In the mid-1980s, the Federal Reserve attempted to close loopholes and stop this new interstate activity that had the effect of merging banking and commerce, but the Supreme Court overnuled it. In 1987, Congress passed the Competitive Equality Banking Act (CEBA), redefining "banks," banning the formation of new nonbank banks, and restricting the growth and new business activities of the 57 existing (grandfathered) nonbank banks. Notably, however, CEBA exempted credit card banks and some other limited purpose banks from the new definition. As a result, commercial enterprises like AT\& T and the Big Three automakers have purchased banks whose primary business line is credit cards.

\footnotetext{
${ }^{14}$ For this study, limited purpose and nonbank banks are defined as follows: banks with ratios of demand deposits to total deposits of less than 5 percent, banks with ratios of commercial loans to total loans of less than 5 percent, banks classified as limited purpose or nonbank banks by their federal regulators, and banks with ratios of credit card loans to total loans of greater than 50 percent. Although this screen is meant to be comprehensive, some banks that could be classified as nonbank banks might still be included, altering state averages.
} 


\section{Table 5}

\section{Return on Average Assets for Credit Card Bank States Versus All States \\ (Deleting Limited Purpose and Nonbank Banks)}

\begin{tabular}{cccccc} 
Year & All U.S. Banks & $\begin{array}{c}\text { Me States } \\
\text { S0 }\end{array}$ & Delaw are & Nevada & South Dakota \\
\hline 1984 & $0.65 \%$ & $0.86 \%$ & $1.13 \%$ & $1.24 \%$ & $0.89 \%$ \\
\hline 1985 & 0.68 & 0.77 & 1.13 & 0.97 & 0.41 \\
\hline 1986 & 0.59 & 0.65 & 1.68 & 0.86 & 0.10 \\
\hline 1987 & 0.04 & 0.47 & 1.66 & 0.94 & 0.68 \\
\hline 1988 & 0.79 & 0.75 & 1.98 & 1.00 & 0.78 \\
\hline 1989 & 0.43 & 0.74 & 1.83 & 1.32 & 1.00 \\
\hline 1990 & 0.43 & 0.54 & 2.26 & 0.71 & 1.19 \\
\hline 1991 & 0.47 & 0.66 & 2.15 & 0.37 & 1.05 \\
\hline 1992 & 0.87 & 1.00 & 2.09 & 0.81 & 1.07 \\
\hline 1993 & 1.14 & 1.22 & 1.90 & 0.93 & 1.48 \\
\hline 1994 & 1.09 & 1.23 & 1.91 & 2.00 & 1.38 \\
\hline 1995 & 1.12 & 1.24 & 1.82 & 1.56 & 1.36
\end{tabular}

SOURCE: FFIEC Reports of Condition and Income

\section{Figure 6}

\section{Coefficient of Variation of Return on Average Assets} 1980-1995

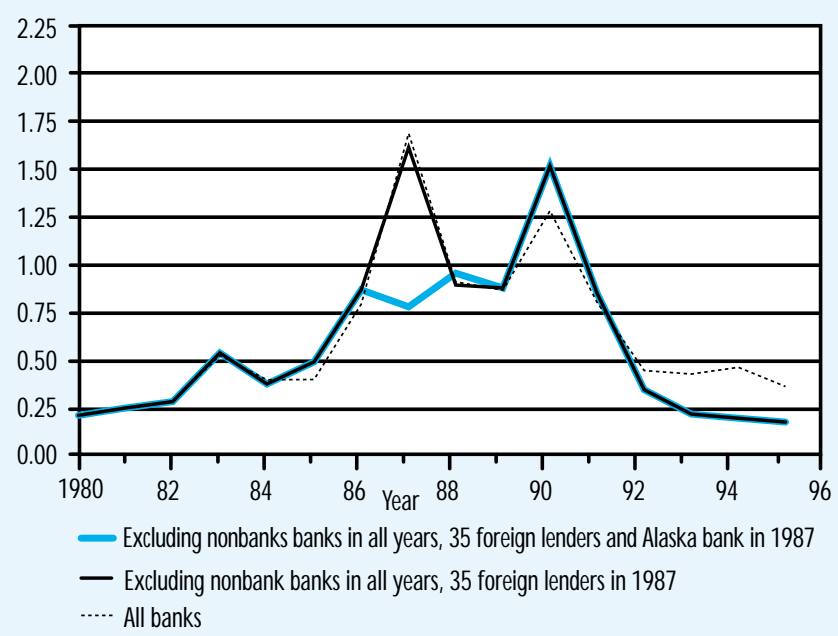

percent when limited purpose and nonbank banks are deleted. It declines by 26 basis points, or 11 percent, in Delaware, and by 180 basis points, or 63 percent, in South Dakota, when these banks are not included in the calculations.

In some states in some years, however, limited purpose and nonbank banks posted sub-average returns, and deleting these banks causes average state ROA to rise. The effect on the dispersion of state average bank earnings in individual years is therefore mixed. Not surprisingly, the largest effect appears in the early 1990s when states like Delaware, N evada, and South Dakota posted average ROA about two to four times as high as the U.S. average. In 1993, for example, the coefficient of variation of state-level ROA declines from 0.43 to 0.23 when the nonbank and limited purpose banks are dropped. But for the 1980-95 period as a whole, the deletion of these banks has little effect on the average annual coefficient of variation, which drops from 0.64 to 0.61 . Even with these deletions, the average ROA for these states is still usually substantially above the national average; the remaining differences can be explained in large part by state-specific factors. N evada's strong performance, for example, can be partially explained by Citicorp's large local credit card operation there, but mostly by a gambling- and mining-based economic boom (Cook, 1996, p. 42).

The combined effect of dropping banks in 1987 that took LDC-loan related loan loss provisions in that year and banks that could be classified as limited-purpose or nonbank banks in all years, is illustrated in Figure 6. The average annual coefficient of variation for the 1980-95 period is 0.61 . The annual coefficient of variation for all banks before the early 1990s is on par with or slightly below that of all banks less nonbanks and banks that took large 1987 LDC loan loss provisions. Beginning in 1991, however, the disparity in earnings between states with credit card banks and all other states widens significantly; the elimination of these banks from the data thus reduces the annual coefficient of variation.

In the end, then, accounting for loan loss provisions associated with LDC debt by large regional and money center banks and the presence of credit card and other nonbank banks results in some slight reductions in the variation in bank 
earnings across states in the 1980s and early 1990s. Much of the sharp increase in variation of state bank earnings over the 1980-95 period remains, however (see Figure 7); a substantial portion of that variation is explained by unusually sharp differences in regional economic performance. The sharp spike in the coefficient of variation that occurs in 1987 is due not to the large loan loss provisions taken by LDC lenders, as hypothesized, but by one troubled Alaska bank (see Figure 6)..$^{15}$ In other years, the rise can be attributed to income declines in energyproducing states (Alaska, Louisiana, Oklahoma, and Texas) and later to the real estate crash and defense downsizing that affected eastern and N ew England states (Connecticut, Massachusetts, N ew Hampshire, New Jersey, New York, Rhode I sland, and Vermont).

\section{CONCLUSION}

U.S. bank earnings tend to vary, often substantially, across states in any given year. This variation was especially pronounced in the 1980s and early 1990s, a period that featured one deep and one rather shallow national recession, several regional economic crises, and a number of significant changes in federal and state banking laws and regulations. We find that each of these factors contributed to the widening disparity in bank earnings among states in this period.

Our primary hypothesis, that state bank earnings are strongly influenced by state-level economic activity, is supported by our econometric tests. State per capita income exerts a strong positive statistical effect on state bank earnings, though the effect of the current year's income is economically small. We suspect that per capita income may not be a good proxy for economic shocks that most directly affect bank earnings-for example, oil crises or commercial real estate crashes.

The LDC debt crisis and the emergence of limited purpose and nonbank banks also increased the disparity in bank earnings across states during the 1980s and

\section{Figure 7}

\section{Coefficient of Variation of Return on Average Assets} 1947-1995

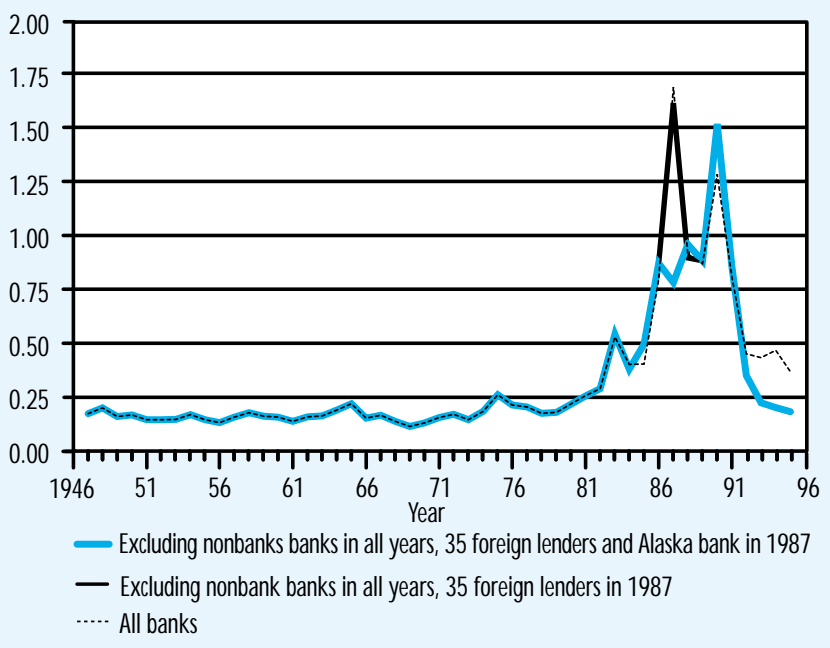

1990s. W hen we delete such banks from the data, the variation in bank earnings in most years of this period is reduced. Most of the variation remains, however, and appears to be linked to regional economic conditions: Energy-belt states in the late 1980s and N ew England states in the early 1990s had markedly lower profit rates than did other states.

Banking observers have speculated that the advent of nationwide interstate branching in 1997 will lessen the dependence of banks on local economic conditions for their profitability and survival. Banks have been able to diversify their loan portfolios geographically through loan sales and participations for a number of years, however, and they were offered a number of new opportunities to do so in the 1980 s with the advent of regional reciprocal and some nation wide interstate banking compacts. Although some large banking organizations have taken advantage of these legal and regulatory changes, others have preferred to stay close to home to take advantage of local business relationships. We thus foresee an industry populated both by banks with extensive interstate operations and by banks with geographically limited operations, because

\footnotetext{
${ }^{15}$ Obviously, the coefficient of variation is very sensitive to large outliers. That $\$ 1.2$ billion bank, Alliance Bank of Anchorage, posted an ROA of - 18.38 percent in 1987, bringing the state average down to - 4.1 percent. The bank failed in 1989. When it is deleted, Alaska's average ROA rises to 0.32 percent and the coefficient of variation for 1987 drops to 0.92 .
} 
both types of organizations appear to have a role to play in U.S. banking markets. Nevertheless, with the 1997 reduction of barriers to branching, we expect the U.S. banking system as a whole to become less dependent on, but not entirely independent of, idiosyncracies in local bank markets.

\section{REFERENCES}

Amos, Orley M., Jr. "The Sensitivity of Regional Income Variation to Cydical Economic Fluctuations," The Review of Regional Studies (Spring 1983), pp. 4-11.

Ausubel, Lawrence M. "The Failure of Competition in the Credit Card Market," American Economic Review (March 1991), pp. 50-81.

Cook, Timothy. "Community Banking in Nevada," Independent Banker (February 1996), pp. 42-44.

Coughlin, Cletus C., and Thomas B. Mandelbaum. "Why Have State Per Capita Incomes Diverged Recently?" this Review (September/ October 1988), pp. 24-36.

Federal Deposit Insurance Corporation. Historical Statistics on Banking, 1993.

Federal Financial Institutions Examination Council. Reports of Condition and Income, 1980-1995.

Gilbert, R. Alton. "Do Bank Holding Companies Act As 'Sources of Strength' for Their Bank Subsidiaries?" this Review (Januaryl February 1991), pp. 3-18.

General Accounting Office. U.S. Credit Card Industry: Competitive Developments Need to be Closely Monitored," GAO/ GGD-94-23, April 1994.

Grammatikos, Theoharry, and Anthony Saunders. "Additions to Bank Loan-Loss Reserves: Good News or Bad News? " Journal of Monetary Economics (March 1990), pp. 289-304.

Harris, Timothy J. "Banks Didn't Bite the Foreign Loan Bullet," Bankers Monthly (February 1988), pp. 42-47.

"Limited Service Banks May Reshape Industry," Payment Systems Newsletter (August 20, 1984).

Ludwig, Eugene A. Remarks Before the Jerome Levy Economics Institute, April 12, 1996.

Peek, Joe, and Eric S. Rosengren. "Bank Real Estate Lending and the New England Capital Crunch," Journal of the American Real Estate and Urban Economics Association (№. 1, 1994), pp. 33-58.

Prickett, William, David S. Swayze, and Dennis Spivack. "A Preview of Delaware's Financial Center Development Act of 1981," Delaware Journal of Corporate Law (Vol. 6, 1981), pp. 104-13.

Ripsom, David B., David S. Swayze, and Molly Sheehan. "A Review of Delaware Banking Developments," Banking Expansion Reporter (November 7, 1983), pp. 1, 13-18.
Rose, Peter S. "Diversification and Interstate Banking," Proceedings of a Conference on Bank Structure and Competition, Federal Reserve Bank of Chicago (May 1995), pp. 296-313.

Samolyk, Katherine A. "U.S. Banking Sector Trends: Assessing Disparities in Industry Performance," Economic Review, Federal Reserve Bank of Cleveland (Quarter 2, 1994a), pp. 2-17.

. . . . . "Banking Conditions and Regional Economic Performance: Evidence of a Regional Credit Channel," Journal of Monetary Economics (October 1994b), pp. 259-78.

Sherwood-Call, Carolyn. "The 1980s Divergence in State Per Capita Incomes: What Does it Tell Us?" Economic Review, Federal Reserve Bank of San Francisco (No. 1, 1996), pp. 14-25.

Sinkey, Joseph F., Jr., and Robert C. Nash. "Assessing the Riskiness and Profitability of Credit-Card Banks," Journal of Financial Services Research (June 1993), pp. 127-50.

Spong, Kenneth. Banking Regulation: Its Purposes, Implementation, and Effects. Federal Reserve Bank of Kansas City, 1994.

Todd, Walker F. "Developing Country Lending and Current Banking Conditions," Economic Review, Federal Reserve Bank of Cleveland (Quarter 2, 1988), pp. 27-36.

Wermiel, Stephen, and Monica Langley. "Limited Purpose Banks Cleared by Supreme Court in 8-0 Decision Ruling Deals a Major Blow to Fed," Wall Street Joumal, January 23, 1986.

Whitehead, David D. "Interstate Banking: Probability or Reality?" Economic Review, Federal Reserve Bank of Atlanta (March 1985), pp. 6-19. 